\title{
Mutộ̂ầsith
}
JURNAL
HUKUM
ISLAM

Vol. 3. No. 2 (2020) 07-12

E-ISSN: : 2723-4681

P-ISSN: 2722-2764

Published online on the journal's website: http://jurnal.iailm.ac.id/index.php/mutawasith

\section{Pandangan Hukum Islam terhadap Penyalahgunaan Napza pada Anak di Bawah Umur}

\author{
Ahmad Ropei \\ Sekolah Tinggi Agama Islam Miftahul Huda Subang, Indonesia \\ ahmadropei88@gmail.com
}

\begin{tabular}{|c|c|c|}
\hline Received: & Revised: & Published: \\
\hline $26-09-2020$ & $21-10-2020$ & $15-12-2020$ \\
\hline \multicolumn{2}{|c|}{ DOI: https://doi.org/ 10.47971/mjhi.v3i2.213 } \\
\hline
\end{tabular}

\begin{abstract}
This study aims to reveal positive legal and Islamic law arrangements against legal sanctions on the abuse of Narcotics, Psychotropics and Addictive Substances (Drugs) by minors. The method used in this research is content analysis (content analysis). The type of data used is qualitative data. The data collection technique used is by means of literature. The results showed that drug abuse committed by minors is regulated in Article 128 paragraph (2) of Law No. 35 of 2009 which states that a child who commits drug abuse cannot be prosecuted. Apart from that, Article 45 also states that a child cannot be prosecuted until he reaches adulthood. Meanwhile, parents of children who are drug abusers are obliged to report to the relevant authorities in order to receive treatment and / or treatment through medical rehabilitation and social rehabilitation. From the point of view of Islamic law, drug abuse committed by minors cannot be punished. This is because minors cannot be held responsible for the crime because they have not been subject to legal imposition (khitob) or because they have not reached aqil-baligh.
\end{abstract}

Keywords: Napza, Law, Penalty, Child

\section{Abstrak}

Penelitian ini bertujuan untuk mengungkap pengaturan hukum positif dan hukum Islam terhadap sanksi hukum penyalahgunaan Narkotika, Psikotropika dan Zat Adiktif (Napza) oleh anak di bawah umur. Metode yang digunakan dalam penelitian ini adalah content analisis (analisis isi). Jenis data yang digunakan adalah data kualitatif. Teknik pengumpulan data yang digunakan adalah dengan cara kepustakaan. Hasil penelitian menunjukan bahwa penyalahgunaan Napza yang dilakukan oleh anak di bawah umur, diatur dalam Pasal 128 ayat (2) UU No. 35 Tahun 2009 yang menerangkan bahwa seorang anak yang melakukan penyalahgunaan Napza, tidak dapat dituntut pidana. Selain daripada itu, dalam KUHP Pasal 45 juga diterangkan bahwa seorang anak tidak dapat dituntut pidana sebelum mencapai dewasa. Sementara itu, bagi orang tua anak pelaku penyalahguna Napza, diwajibkan untuk melapor kepada pihak berwenang agar mendapatkan pengobatan dan/atau perawatan melalui rehabilitasi medis dan rehabilitasi sosial. Dalam sudut pandang hukum Islam, penyalahgunaan Napza yang dilakukan oleh anak di bawah umur, tidak dapat dijatuhi hukuman. Hal ini disebabkan anak di bawah umur tidak dapat dimintai pertanggungjawaban pidana dikarenakan belum dapat dikenakan pembebanan hukum (khitob) atau karena belum mencapai aqil-baligh. 


\section{PENDAHULUAN}

Seiring dengan perkembangan zaman seperti sekarang ini, semakin banyak terjadi persoalan yang dihadapi oleh bangsa Indonesia dalam kehidupan sehari hari. Salah satu permasalahan yang kini sedang dihadapi bangsa, adalah persoalan penyalahgunaan "Napza" yang merupakan singkatan dari Narkotika, Psikotropika dan Zat Adktif. Istilah tersebut pada dasarnya mengacu pada sekelompok zat yang umumnya mempunyai resiko mengganggu sistem kerja saraf otak dan dapat membuat kecanduan bagi penggunanya. Napza itu sendiri merupakan bahan/zat yang bila masuk ke dalam tubuh akan mempengaruhi tubuh terutama susunan syaraf pusat/otak sehingga jika disalahgunakan akan menyebabkan gangguan fisik, psikis/jiwa dan fungsi sosial. Karena terjadi kebiasaan, ketagihan (adiksi) serta ketergantungan (dependensi). ${ }^{1}$ Definisi ini sebagaimana diterangkan oleh Edikarsono yang mengemukakan bahwa narkotika ialah zat atau bahan aktif yang bekerja pada sistem syaraf pusat (otak), yang dapat menyebabkan penurunan sampai kehilangan kesadaran dari rasa sakit (nyeri) serta dapat menimbulkan ketergantungan (ketagihan). ${ }^{2}$ Penyalahgunaan Napza memiliki dampak terhadap berbagai segi, dampak tersebut terlihat pada fisik, prikis maupun sosial. ${ }^{3}$ Penyalahgunaan Napza telah menjadi masalah sosial di masyarakat yang meresahkan. Dampak yang ditimbulkannya pun tidak hanya pada dampak fisik saja, tetapi juga dampak pada lingkungan sosial. Penyalahgunaan narkotika merupakan masalah yang memprihatinkan dunia internasional. ${ }^{4}$ Karena itu penyalahgunaan Napza menjadi persoalan serius yang hampir dihadapi oleh berbagai negara di dunia termasuk Indonesia.

Penyalahgunaan Napza sekarang ini tidak hanya mengenai orang-orang dewasa saja, akan tetapi juga menimpa kepada anak-anak di bawah umur. Anak sebagai bagian dari generasi muda yang merupakan penerus cita-cita perjuangan bangsa dan sumber daya manusia bagi pembangunan nasional, saat ini dihadapkan pada permasalahan dan tantangan yang cukup serius diantaranya adalah keterlibatan anak pada penyalahgunaan Napza. Persoalan penyalahgunaan Napza yang melibatkan anak-anak di bawah umur merupakan permasalahan serius yang dihadapi bangsa, oleh karena anak merupakan generasi penerus kemajuan bangsa. Oleh sebab itu, penyalahgunaan Napzayang menimpa anak-anak bangsa, harus secara cepat diatasi. Penyalahgunaan Napza yang terjadi pada anak di bawah umur, dilatarbelakangi oleh berbagai faktor mulai dari kurangnya pengawasan dari orang tua, faktor keluarga (broken home), lingkungan tempat tinggal, dan lain sebagainya. ${ }^{5}$ Mengenai definisi anak itu sendiri apabila merujuk rumusan pada Pasal 1 ayat (1) UU No. 23 tahun 2002tentang Perlindungan Anak, disebutkan bhwa anak adalah "seseorang yang belum berusia 18 tahun, termasuk anak dalam kandungan". Defenisi ini mencakup janin, bayi, anak-anak sampai berumur 18 tahun.

\footnotetext{
${ }^{1}$ Oktia Woro Kasmini Handayani, Siti Riza Azmiyati, Widya Hary Cahyati, "Gambaran Penggunaan Napza Pada Anak Jalanan Di Kota Semarang," Jurnal Kesehatan Masyarakat, Vol. 9 No. 2 (2014): 137-43.

2 Edikarsono, Mengenal Kecanduan Narkoba Dan Minuman Keras (Bandung: Yrama Widya, 2004). 12

${ }^{3}$ Catur Mei Wulandari, “Faktor-Faktor Yang Mempengaruhi Penyalahgunaan Napza pada Masyarakat di Kabupaten Jember," Jurnal Farmasi Komunitas. Vol. 2, No. 1 (2015): 1-4.

${ }^{4}$ Uyat Suyatna, "Evaluasi Kebijakan Narkotika Pada 34 Provinsi Di Indonesia,Jurnal IImu-IImu Sosial Dan Humaniora. Vol. 20, No. 2 (2018): 168-76.

${ }^{5}$ Alya Nurmaya, "Penyalahgunaan Napza Di Kalangan Remaja (Studi Kasus Pada 2 Siswa Di MAN 2 Kota Bima)," Jurnal Psikologi Pendidikan \& Konseling. Vol. 2, No. 1 (2016): 26-32.
} 
Undang-undang ini juga mengatur tanggung jawab sosial anak dan tanggung jawab anak dimuka hukum.

Pemerintah sebagai pihak yang berwenang telah berupaya mengatur segala persoalan yang terjadi pada warga negaranya, hal ini salah satunya adalah dengan memberlakukan UU No. 35 Tahun 2009 tentang Narkotika. Undang-undang No. 35 Tahun 2009 tentang Narkotika merupakan dasar hukum yang diperuntukkan bagi pengaturan penggunaan Narkotika dan zat Adiktif lainnya. Dalam kaitannya dengan penyalahgunaan dengan pelaku anak di bawah umur, seorang pelaku yang masih berada dalam usia anak-anak apabila telah dilaporkan oleh orang tuanya, tidak dapat diancamkan sanksi pidana. Hal ini sebagaimana disebutkan dalam Pasal 128 ayat (2) UU No. 35 Tahun 2009 bahwa "Pecandu Narkotika yang belum cukup umur dan telah dilaporkan oleh orang tua atau walinya sebagaimana dimaksud dalam Pasal 55 ayat (1) tidak dituntut pidana".

Islam sebagai agama yang mengajarkan ketentraman hidup, baik di dunia maupun di akhirat, tentunya memiliki sudut pandang tersendiri mengenai penyalahgunaan Napza yang dilakukan oleh anak-anak di bawah umur. Napza itu sendiri dalam hukum Islam dipandang sebagai sesuatu yang memabukkan dan dapat mempengaruhi kesadaran akal. Sesuatu yang memabukkan dalam hukum Islam disebut dengan khamar. Hal ini didasarkan pada sebuah hadits Nabi Saw yang menyatakan bahwa:

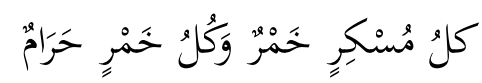

Artinya: "Setiap yang memabukkan itu khamr, dan setiap khamr itu haram" (H.R, Muslim).

Keharaman mengkonsumsi khamr, dijelaskan dalam firman Allah Swt, al-Qur'an surat al-Maidah ayat 90 yang artinya: "Hai orang-orang yang beriman, Sesungguhnya (meminum) khamar, berjudi, (berkorban untuk) berhala, dan mengundi nasib dengan anak panah adalah perbuatan keji dan termasuk perbuatan syaitan. Maka jauhilah perbuatan-perbuatan itu agar kamu beruntung". Dalam ayat lain, Allah Swt juga menerangkan bahwa khamr itu lebih banyak madharatnya daripada manfaatnnya. Hal ini sebagaimana dinyatakan dalam al-Qur'an surat AlBaqarah ayat 219 yang artinya: "Mereka bertanya kepadamu (Muhammad) tentang khamar dan judi. Katakanlah bahwa pada keduanya terdapat dosa besar dan ada beberapa manfaat bagi manusia, tetapi dosa keduanya lebih besar daripada manfaatnya".

Mengingat Napza memiliki dampak yang sangat buruk dan juga sebagai sesuatu yang dilarang untuk dikonsumsi baik dalam hukum positif maupun dalam hukum Islam, maka dipandang perlu untuk melakukan pengkajian lebih mendalam mengenai pandangan hukum Islam terhadap penyalahgunaan Napza oleh anak di bawah umur dan sanksi hukumnya.

\section{METODE}

Metode yang digunakan dalam penelitian ini adalah content analysis (analisis isi), yaitu suatu metode yang dilaksanakan dengan menganalisis suatu dokumen-dokumen atau data yang bersifat normatif. Jenis data yang digunakan adalah jenis kualitatif, yaitu data yang bersifat deskriptif berkaitan dengan data-data yang diperlukan dalam penelitian. Sumber data dalam penelitian ini terdiri atas dua bahan hukum, yaitu: Pertama, bahan hukum perimer, yakni bahan utama yang digunakan dalam penelitian. Kedua, bahan hukum sekunder, yakni 
bahan hukum pembantu yang bersumber dari berbagai macam literatur seperti buku-buku pustaka, kitab-kitab, artikel, majalah yang menunjang dan berkaitan dengan tindak pidana pengguna Narkotika oleh dibawah umur.

Teknik pengumpulan data dilakukan dalam rangka mencari dan mengumpulkan data penelitian adalah dengan studi kepustakaan (library research), yang dilakukan dengan cara membaca, mempelajari, menelaah, memahami dan menganalisis serta menyusunnya dari berbagai literatur dan peraturan-peraturan yang ada relevansinya dengan masalah yang diangkat dalam penelitian. Adapun analisis yang digunakan adalah deskriftif-kualitatif, yaitu analisis yang dilakukan dengan memaparkan data-data yang diperoleh dan kemudian menganalisa sehingga mendapatkan sebuah kesimpulan. Langkah-langkah dalam analisis data tersebut meliputi: (1) Menelaah semua data yang terkumpul dari berbagai sumber, baik primer atau sekunder; (2) Mengklasifikasi seluruh data ke dalam satuan-satuan permasalahan sesuai dengan perumusan masalah; (3) Manganalisis unsur-unsur dalil yang digunakan tentang masalah yang dibahas; (4) Menarik kesimpulan hasil analisis tentang masalah yang dibahas.

\section{HASIL DAN PEMBAHASAN}

\section{Deskripsi Umum Napza dan Dampak Penyalahgunaannya}

Istilah "Napza” merupakan singkatan dari Narkotika, Psikotropika dan Zat Adiktif. Istilah Napza pada dasarnya lebih sering dikenal di dunia kesehatan. Selain daripada "Napza", istilah lain yang juga poluler di kalangan masyarakat untuk menyebut Napza adalah istilah "Narkoba" yaitu singkatan dari Narkotika dan obat-obatan berbahaya. ${ }^{6}$ Kedua istilah tersebut merujuk pada jenis zat baik berupa obat-obatan maupun lainnya yang terlarang untuk digunakan oleh masyarakat secara luas.Karena itu Napza seringkali disebut sebagai obat-obatan terlarang yang penggunaannya sangat dibatasi dan harus dalam pengawasan yang sangat ketat.Karena itu Napza tidak boleh disalahgunakan oleh sembarang orang.

Napza adalah sekelompok zat-zat yang apabila dikonsumsi oleh manusia baik dengan cara dihirup, dihisap, ditelan, atau disuntikkan maka ia akan mempengaruhi susunan saraf pusat (otak) dan akan menyebabkan ketergantungan. Akibatnya, sistem kerja otak dan fungsi vital organ tubuh lain seperti jantung, pernafasan, peredaran darah dan lain-lain akan berubah meningkat pada saat mengkonsumsi dan akan menurun pada saat tidak dikonsumsi (menjadi tidak teratur). ${ }^{7}$ Zainuddin menerangkan bahwa Narkotika adalah zat atau obat yang berasal dari tanaman atau bukan tanaman baik sintesis maupun semi sintasis yang dapat menyebabkan penurunan atau perubahan kesadaran, hilangnya rasa, mengurangi sampai menghilangkan rasa nyeri. Narkotika dalam bahasa arab disebut mukhaddirat. Maksudnya menunjukan kepada sesuatu yang terselubung, kegelapan, atau kelemahan. Oleh karena itu, dilihat dari arti bahasa dapat disimpulkan bahwa narkotika identik dengan kelemahan dan kelesuhan yang menyerang badan dan anggota tubuh lainnya sebagai mana halnya pengaruh minuman keras. ${ }^{8}$ Pengertian tersebut diperkuat dengan definisi Narkotika sebagaimana diterangkan oleh Pasal 1 ayat (1),

${ }^{6}$ Amru Eryandi Siregar, Madiasa Ablisar, Mahmud Mulyadi, Marlina. "Penjatuhan Sanksi Pidana Dibawah Batas Minimum Ancaman Hukuman Bagi Anak Pelaku Tindak Pidana Narkotika," USU Law Journa/Vol. 5, No. 2 (2017): 182-91.

7 Lidya Harlina Martono dan Satya Joewana, Membantu Pemulihan Pecandu Narkoba Dan Keluarganya (Jakarta: Balai Pustaka, 2006). 1

8 Zainuddin Ali, Hukum Pidana Islam (Jakarta: Sinar Grafika, 2007). 80 
UU No. 35 Tahun 2009, yang menyatakan bahwa "Narkotika ialah zat atau obat yang berasal dari tanaman atau bukan tanaman, baik sintetis maupun semisintetis, yang dapat menyebabkan penurunan atau perubahan kesadaran, hilangnya rasa, mengurangi sampai menghilangkan rasa nyeri, dan dapat menimbulkan ketergantungan". Apabila diperhatikan, Narkotika memiliki kinerja dengan sasaran utama sistem kerja saraf otak yang kemudian menjadi terganggu dan mengakibatkan kehilangan kesadaran bagi pemakainya.

Berdasarkan uraian di atas, dapat disimpulkan bahwa Napza atau Narkotika dan Zat adiktif lainnya yang berbahaya adalah zat yang dapat mempengaruhi kinerja sistem saraf pusat dan dapat mengakibatkan ketergantungan atau membuat kecanduan pemakainya. Pemakai Narkotika akan mengalami gangguan perubahan mental dan perilaku di luar kesadaran normal. Pada prinsipnya, Napza merupakan zat berbahaya yang tidak sembarangan dapat dikonsumsi oleh setiap orang. Karena apabila disalahgunakan, akan mengakibatkan dampak negatif baik terhadap psikis, maupun fisik seseorang dan pada tingkatan yang paling buruk adalah dapat mengakibatkan kematian pada pemakainya karena sebab over dosis (kelebihan dosis).Penggunaan Napza harus dengan pengawasan para tenaga medis yang hanya boleh digunakan untuk kepentingan medis dan pengembangan ilmu pengetahuan.

Apabila mengacu kepada UU No. 35 Tahun 2009 tentang Narkotika, maka penggolongan jenis Narkotika dapat dikategorikan kepada tiga golongan sebagaimana diterangkan dalam Pasal 6, yaitu terdiri dari: Narkotika Golongan I, golongan II dan Narkotika golongan III. Golongan I, yaitu jenis narkotika yang hanya dapat digunakan untuk tujuan ilmu pengetahuan, dan tidak ditujukan untuk terapi serta mempunyai potensi sangat tinggi dalam menimbulkan ketergantungan. Jenis Narkotika golongan I ini, seperti: heroin/putaw, kokain, ganja dan lain-lain. Adapun golongan II, yaitu narkotika yang berkhasiat untuk pengobatan yang dipakai sebagai pilihan dan dapat digunakan untuk kepentingan terapi atau tujuan pengembangan ilmu pengetahuan serta mempunyai potensi tinggi mengakibatkan ketergantungan. Seperti: morfin, peditin, betamoprodina, difenoksin, rasemorfan dan lain-lain. Sementara golongan III, yaitu narkotika yang berkhasiat untuk pengobatan dan banyak digunakan dalam terapi atau tujuan pengembangan ilmu pengetahuan serta mempunyai potensi ringan dalam mengakibatkan ketergantungan. Seperti: kodein, propiram, buprenorfina, dekstropropoksifena dan lain-lain. ${ }^{9}$

Secara umum dampak yang dihasilkan dari penggunaan Narkotika dan zat adiktif lainnya seperti Psikotropika, dapat dilihat sebagai berikut: Pertama, Defresan yaitu pengaruh poenggunaan Napza pada pengurangan aktifitas fungsional tubuh. Napza jenis ini membuat pemakainnya merasa tenang, pendiam, dan bahkan membuatnnya tertidur dan tidak sadarkan diri. Dampak jangka pendek Napza jenis ini yaitu membuat pemakainnya menjadi rileks, mengurangi rasa malu, menekan rasa gelisah. Adapun dampak jangka panjang dari penggunaan Napza jenis ini, yaitu mengakibatkan rasa kantuk, penyebutan kata tidak jelas, penurunan kemampuan menilai, daya ingat dan koordinasi, mengambang, pingsan, intoksinasi akut, pernafasan tertekan, grastritis, memburuknya diabetes atau epilepsy yang sudah ada, tidak sadar, ketergantungan yang berat, kematian akibat intoksinasi, penyerangan seksual yang tidak atau sedikit diingat sesudahnya. Napza yang tergolong pada pengaruh defresan ini, meliputi:

${ }^{9}$ BNN, Pusat Pencegahan Badan Narkotika Nasional Republik Indonesia Tahun 2009 (Jawa Barat: Bidang Pencegahan Badan Narkotika Provinsi Jawa Barat, 2009). 55 
Opiodia (Morfin, Heroin/Putaw, Kodein), Sedatif (penenang), Hipnotik (obat tidur), Tranquilizer (anti cemas), alkohol dalam dosis rendah, dan lain-lain.Kedua, stimulan yaitu pengaruh penggunaan Napza yang mengakibatkan dapat merangsang fungsi tubuh yang dapat meningkatkan kegairahan kerja. Jenis ini membuat pemakainya menjadi aktif, segar dan bersemangat. Dampak jangka pendek pengaruh stimulant, yaitu rasa gembira, tidak mudah lelah, penenang, perangsang, pembangkit gairah seksual, mengurangi selera makan, penurunan berat badan. Sedangkan akibat janga panjang dari pengaruh stimulants ini meliputi: denyut nadi dan tekanan darah meningkat, insomnia, gemetar, paranoia, hiperaktif, kelelahan, penurunan berat badan, henti jantung, penurunan kemampuan menilai, psikotik, memburuknya agresifitas, perilaku kekerasan, perubahan keperibadian, kerusakan permanen system syaraf pusat, pendarahan intra serebral, kerusakan oto, infeksi atau kebocoran sekat hidung, disfungsi organ, sisstem syaraf, hati, dan ginjal. Jenis Napza ini, meliputi: Kokain, Amfetamin (Shabu, Ekstasi), Kafein.Ketiga, Halusinogen yaitu pengaruh penggunaan Napza yang dapat menimbulkan efek halusinasi yang bersifat merubah perasaan dan pikiran dan seringkali menciptakan daya pandang yang berbeda sehingga seluruh perasaan dapat terganggu. Jenis Napza pada pengaruh ini tidak dipergunakan dalam terapi medis. Pengaruh jangka pendek Halusinogen, yaitu perubahan persepsi dan keduniawian lainnya, relaksasi, mengurangi kegelisahan. Adapun bahaya jangka panjang dari pengguanaan jenis Napza ini adalah peningkatan tekanan darah, gemetar, efek psikiatrik jangka panjang, serangan panic, paranoia, gangguan pendengaran dan penglihatan, halusianasi, penurunan kemampuan menilai, meningkatkan selera makan, penurunan daya ingat dan kognitif, berhenti menstruasi, berkurangnya produksi sperma, bronchitis. Napza juenis ini, seperti: Kanabis (Ganja), LSD, Mescalin, Fenslikidin, berbagai jenis jamur, tanaman kecubung, dan lain-lain. ${ }^{10}$

Berdasarkan keterangan tersebut di atas maka penyalahgunaan Napza merupakan bagian dari salah satu ketegangan psikososial dan berdampak pada berbagai sendi kehidupan sosial terutama menimpa kepada penyalahguna itu sendiri berupa berbagai penderitaan baik yang dialami secara fisik, psikis, spiritual maupun sosial yang berakibat pada perasaan tertekan serta melemahnya kemampuan untuk bangkit dari keterpurukan. ${ }^{11}$ Sebagai persoalan psikososial, penyalahgunaan Napza ini juga turut berkontribusi pada massifnya berbagai tindak kriminal seperti mencuri, merampok, pemerkosaan, pembunuhan, pelecehan seksual dan lain sebagainya. ${ }^{12}$ Begitu seriusanya dampak yang ditimbulkan dari penyalahgunaan Napza menuntut semua pihak terutama pemerintah dan penegak hukum untuk melakukan pemberantasan penyalahgunaan Napza di tengah-tengah masyarakat. Upaya pencegahan dan penanggulangan penyalahgunaan Napza merupakan usaha-usaha yang dapat dilakukan dalam rangka mewujudkan sumber daya manusia Indonesia seutuhnya. ${ }^{13}$ Bagaimanapun penggunaan Napza tanpa pengendalian dan pengawasan yang ketat serta bertentangan dengan peraturan

10 BNN.Pusat Pencegahan Badan Narkotika Nasional Republik Indonesia Tahun 2009. 143-144

11 Ilmi Hidayati, “Metode Dakwah Dalam Menguatkan Resilensi Korban Penyalahgunaan Narkotika, Psikotropika, Dan Zat Adiktif Lainnya (NAPZA)," Jurnal IImu Dakwah. Vol. 36, No. 1 (2016): 170-87.

12 Liky Faizal, "Penyalahgunaan Narkoba Dalam Pandangan Islam (Upaya Pencegahan Dan Solusi Penyalahgunaan Narkoba)," Jurnal ASAS. Vol. 7, No. 35 (2015): 131-36.

${ }^{13}$ Fransiska Novita Eleanora, "Bahaya Penyalahgunaan Narkoba Serta Usaha Pencegahan Dan Penanggulangannya," Jurnal Hukum. Vol. XXV, No. 1 (2011): 439-452. 
perundang-undangan yang beralaku adalah kejahatan, karena sangat merugikan dan mengancam kehidupan manusia dalam kehidupan berbangsa dan bernegara.

\section{Konsep Pertanggung-Jawaban Pidana Anak dalam Hukum Pidana Indonesia dan Hukum Islam}

Anak merupakan cikal bakal lahirnya suatu generasi baru yang merupakan penerus citacita perjuangan bangsa dan sumber daya manusia bagi pembangunan Nasional. Anak adalah asset bangsa, masa depan bangsa dan Negara dimasa yang akan datang berada ditangan anak sekarang. Semakin baik keperibadian anak sekarang maka semakin baik pula kehidupan masa depan bangsa. Begitu pula sebaliknya, Apabila keperibadian anak tersebut buruk maka akan bobrok pula kehidupan bangsa yang akan datang.Pada umumnya orang berpendapat bahwa masa kanak-kanak merupakan masa yang panjang dalam rentang kehidupan. Bagi kehidupan anak, masa kanak-kanak seringkali dianggap tidak ada akhirnya, sehingga mereka tidak sabar menunggu saat yang didambakan yaitu pengakuan dari masyarakat bahwa mreka bukan lagi anak-ank tapi orang dewasa.

Pasal 1 ayat (1) Undang Undang No 23 Tahun 2002, menerangkan bahwa anak adalah seseorang yang belum berusia 18 (delapan belas) tahun, termasuk anak yang masih dalam kandungan. Sementara itu, pengertian anak menurut KUHP Pasal 45 yaitu seorang yang belum cukup umur, yaitu mereka yang melakukan perbuatan (tindak pidana) sebelum umur 16 (enam belas tahun). ${ }^{14}$ Sedangkan dalam Pasal 47 UU No. 1 tahun 1974 tentang perkawinan, dinyatakan bahwa anak adalah seorang yang belum mencapai usia 18 (delapan belas tahun) atau belum pernah melangsungkan perkawinan ada di bawah kekuasaan orang tuanya.

Dalam hukum Islam, istilah anak disebut dengan "shabiy" dalam hubungannya dengan pengertian terhadap anak di bawah umur yang melakukan perbuatan pidana. Hukum Islam tidak menimpakan pertanggungjawaban pidana yang dilakukan oleh anak di bawah umur sampai ia mencapai usia baligh. Hal ini sebagaimana diterangkan pada suatu kaidah tentang gugurnya pertanggungjawaban pidana:

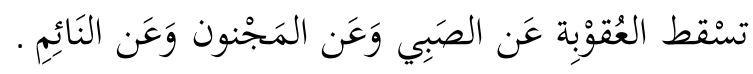

Artinya: "Hukuman gugur dari (perbuatan jarimah yang dilakukan oleh) anak-anak, orang gila, dan orang yang sedang tidur" ${ }^{15}$

Mengenai batas-batas seorang anak dikatakan telah mencapai usia baligh. Di kalangan ulama Syafi'iyyah, batasan baligh bagi laki-laki maupun perempuan dengan sempurnanya usia 15 tahun, telah mengalami mimpi basah dan keluar mani, dan haidh bagi perempuan yang dimungkinkan terjadi ketika mencapai umur 9 tahun.

Hukum pidana mendapat kesulitan ketika dihadapkan pada kejahatan yang timbulkan oleh anak di bawah umur. Pemidanaan anak yang menghadapi masalah hukum terutama terkaitan sebagai pemakai Napza oleh anak dibawah umur harus mengutamakan kepentingan yang terbaik untuk anak tersebut. Anak wajib dilindungi agar tidak menjadi korban baik secara langsung maupun secara tidak langsung. ${ }^{16}$ Dalam sistem pemidanaan Indonesia, seorang anak

\footnotetext{
${ }^{14}$ Andi Hamzah, KUHP \& KUHAP (Jakarta: Rineka Cipta, 2008). 45

15 Jaih Mubarok dan Enceng Arif Faizal, Kaidah Fiqh Jinayah (Asas-Asas Hukum Pidana Islam) (Bandung: Pustaka Bani Quraisy, 2004). 76

${ }^{16}$ Alpi Sahari \& Surya Perdana Dimas Adit Sutono, "Penerapan Sanksi Pidana Kepada Anak Dibawah Umur Pemakai Narkotika (Studi Pada Polrestabes Medan)," Journal Sociaty Law (JSL)Vol. 1, No. 1 (2020): 14-24.
} 
tidak dapat dituntut untuk dijatuhi hukuman oleh karena seorang anak belum bisa dikatakan cakap hukum. KUHP Pasal 45 menerangkan bahwa: "Dalam hal penuntutan pidana terhadap orang yang belum dewasa karena melakukan suatu perbuatan sebelum umur enam belas tahun, hakim dapat menentukan: memerintahkan supaya yang bersalah dikembalikan kepada orang tuanya, walinya atau pemeliharaannya, tanpa pidana apapun. ${ }^{17}$ Pasal $45 \mathrm{KUHP}$ tersebut dapat dipahami bahwa anak yang masih di bawah umur tidak dapat dituntut pidana. Maksudnya adalah tidak dapat dijatuhi sanksi hukum pidana. Pada prinsipnya hukum pidana ditujukan kepada orang dewasa yang dalam istilah hukum positif disebut dengan cakap hukum. Demikian juga dalam sistem hukum Islam yang memberikan perlakuan berbeda pada anak yang terjerat melakukan perbuatan pidana (jarimah). Dalam hukum Islam, pembebanan hukum hanya diberlakukan kepada orang yang sudah aqil baligh (mukallaf). Indikasi orang yang sudah mencapai usia akil baligh: Pertama, sempurnanya seorang anak pada usia 15 tahun. Kedua, anak yang bersangkutan sudah pernah mengalami mimpi bersenggama/bersetubuh. Ketiga, sudah haidh bagi anak perempuan. Apabila indikasi-insikasi tersebut, salah satunya terjadi pada seorang anak, maka anak dalam kondisi ini sudah beralih kepada usia dewasa dan dapat dikenai khitob (pembebanan) hukum syara' disebabkan anak sudah dianggap aqil-baligh.

Berdasarkan uraian tersebut dapat disimpulkan bahwa pertanggungjawaban pidana terhadap anak di bawah umur menjadi terhapus. Baik dalam hukum pidana Indonesia maupun dalam hukum pidana Islam, sanksi pidana tidak dapat dijatuhkan kepada seorang anak. Anak mendapatkan perlakukan khusus tidak seperti umumnya orang dewasa. Dalam hukum pidana Islam, hilangnya peretanggungjawaban pidana bagi anak disebabkan seorang anak belum mendapatkan pembebanan hukum syari'at sampai ia menjadi mukallaf. Hukum pidana Islam menjadikan tidak sempurnanya suatu perbuatan pidana apabila dilakukan oleh anak di bawah umur atau tidak aqil baligh. Dalam perumusan tindak pidana (jarimah), disyaratkan pelaku harus dapat dimintai pertanggungjawaban pidana (al-masuliyyah al-jinaiyyah), sebagai unsur moril (rukun adaby) suatu tindak pidana. Unsur moril (rukun adaby) disebut dengan pertanggung jawaban pidana ${ }^{18}$. Maksudnya adalah pembuat jarimah atau pembuat tindak pidana atau delik haruslah orang yang dapat mempertanggungjawabkan perbuatannya. Oleh karena itu pembuat jarimah haruslah orang yang dapat memahami hukum, mengerti isi beban, dan sanggup menerima beban tersebut. Orang yang diasumsikan memiliki kriteria tersebut adalah orang-orang yang mukallaf, sebab hanya merekalah yang terkena khitab (panggilan/pembebanan) atau taklif .

\section{Penyalahgunaan Napza oleh Anak di Bawah Umur Menurut Hukum Pidana Indonesia}

UU No. 35 Tahun 2009 tentang Narkotika merupakan salah satu undang-undang yang difokuskan untuk mengatur masalah penggunaan Narkotika. Undang-undang ini sebenarnya merupakan undang-undang pengganti dari undang-undang sebelumnya, yaitu UU No. 22 Tahun 1997 tentang Narkotika sudah dianggap tidak lagi sesuai dengan perkembangan situasi dan kondisi yang berkembang untuk menanggulangi dan memberantas tindak pidana tersebut. UU No. 35 Tahun 2009 tentang Narkotika, mulai berlaku pada 12 Oktober tahun 2009 dan dimuat dalam Lembaran Negara RI Tahun 2009 No. 5062. Latar belakang diundangkannya UU

17 Hamzah, KUHP \& KUHAP. 23

18 Rahmat Hakim, Hukum Pidana Islam (Bandung: Pustaka Setia, 2020). 53 
No. 35 Tahun 2009 ini yaitu bahwa Narkotika di satu sisi merupakan obat atau bahan yang bermanfaat di bidang pengobatan atau pelayanan kesehatan dan pengembangan ilmu pengetahuan dan di sisi lain dapat pula menimbulkan ketergantungan yang sangat merugikan apabila disalahgunakan atau digunakan tanpa pengendalian dan pengawasan yang ketat dan saksama; bahwa mengimpor, mengekspor, memproduksi, menanam, menyimpan, mengedarkan, dan/atau menggunakan Narkotika tanpa pengendalian dan pengawasan yang ketat dan saksama serta bertentangan dengan peraturan perundang-undangan merupakan tindak pidana Narkotika karena sangat merugikan dan merupakan bahaya yang sangat besar bagi kehidupan manusia, masyarakat, bangsa, dan negara serta ketahanan nasional Indonesia; bahwa tindak pidana Narkotika telah bersifat transnasional yangdilakukan dengan menggunakan modus operandi yang tinggi, teknologi canggih, didukung oleh jaringan organisasi yang luas, dan sudah banyak menimbulkan korban, terutama di kalangan generasi muda bangsa yang sangat membahayakan kehidupan masyarakat, bangsa, dan negara sehingga UU No. 35 Tahun 2009 kemudian diundangkan dan diberlakukan. Dengan mengetahui berbagai macam bahaya yang ditimbulkan atas penyalahgunaan narkotika, maka segala macam bentuk penyalahgunaan barang haram tersebut pun diatur dalam UU No. 35 Tahun 2009 tentang Narkotika. Pembentukan undang-undang tersebut merupakan gambaran gencarnya negara ini mempertahankan kriminalisasi terhadap pengguna Narkotika. Selain itu, pembentukan undang-undang tersebut merupakan perwujudan konsistensi sikap proaktif Indonesia mendukung gerakan dunia internasional dalam memerangi segala bentuk tindak pidana Narkotika. Dalam UU No. 35 Tahun 2009 tentang Narkotika, juga dirumuskan mengenai pasal tentang kedudukan lembaga negara, yaitu BNN (Badan Narkotika Nasional) yang berwenang melakukan pencegahan dan sekaligus mengawasi penggunaan Narkotika di Indonesia.

Penyalahgunaan Napza merupakan bagian dari suatu perbuatan pidana atau tindak pidana disebabkan perbuatan ini bertentangan dengan pertauran hukum yang berlaku. Selain daripada itu, terhadap penyalahgunaan Napza juga disertai rumusan sanksi hukum pada bab ketentuan pidana. Dalam Undang-undang No. 35 Tahun 2009, ketentuan pidana perbuatan tersebut dicantumkan pada bab XV mulai dari Pasal 111 sampai dengan Pasal 147. Sementara itu, UU No. 5 Tahun 1997 tentang Psikotropika juga telah diatur secara khusus ketentuan pidana sebagaimana ditetapkan pada BAB XIV pasal 59 sampai dengan Pasal 72, seluruhnya merupakan delik kejahatan. Tindak pidana di bidang psikotropika, antara lain berupa perbuatan-perbuatan seperti memproduksi dan/atau mengedarkan secara gelap, maupun menyalahgunakan psikotropika merupakan perbuatan yang merugikan masyarakat dan negara.

Berdasarkan UU No. 35 Tahun 2009, dapat diketahui bahwa tindak pidana yang menyangkut Penyalahgunaan Napza, diancam oleh sanksi hukum, sebagaimana dirumuskan, diantaranya dalam Pasal 128 sebagai berikut:

(1) Orang tua atau wali dari pecandu yang belum cukup umur, sebagaimana dimaksud dalam Pasal 55 ayat (1) yang sengaja tidak melapor, dipidana dengan pidana kurungan paling lama 6 (enam) bulan atau pidana denda paling banyak Rp1.000.000,00 (satu juta rupiah).

(2) Pecandu Narkotika yang belum cukup umur dan telah dilaporkan oleh orang tua atau walinya sebagaimana dimaksud dalam Pasal 55 ayat (1) tidak dituntut pidana. 
(3) Pecandu Narkotika yang telah cukup umur sebagaimana dimaksud dalam Pasal 55 ayat (2) yang sedang menjalani rehabilitasi medis 2 (dua) kali masa perawatan dokter di rumah sakit dan/atau lembaga rehabilitasi medis yang ditunjuk oleh pemerintah tidak dituntut pidana.

(4) Rumah sakit dan/atau lembaga rehabilitasi medis sebagaimana dimaksud pada ayat (3) harus memenuhi standar kesehatan yang ditetapkan oleh Menteri.

Kemudian dalam Pasal 129 disebutkan bahwa: "Dipidana dengan pidana penjara paling singkat 4 (empat) tahun dan paling lama 20 (dua puluh) tahun dan denda paling banyak Rp. 5.000.000.000,00 (lima miliar rupiah) setiap orang yang tanpa hak atau melawan hukum: (a) memiliki, menyimpan, menguasai, atau menyediakan Prekursor Narkotika untuk pembuatan Narkotika; (b) memproduksi, mengimpor, mengekspor, atau menyalurkan Prekursor Narkotika untuk pembuatan Narkotika; (c) menawarkan untuk dijual, menjual, membeli, menerima, menjadi perantara dalam jual beli, menukar, atau menyerahkan Prekursor Narkotika untuk pembuatan Narkotika; (d) membawa, mengirim, mengangkut, atau mentransito Prekursor Narkotika untuk pembuatan Narkotika.

Ancaman hukuman berupa pidana penjara bagi pelaku penyalahguna Napza, dijatuhkan dalam rangka memberikan pembalasan sekaligus pengajaran kepada pelaku kejahatan. Efektifitas pidana penjara setidaknya dapat ditinjau dari dua aspek pokok tujuan pemidanaan, yaitu aspek perlindungan masyarakat dan aspek perbaikan si pelaku. Yang dimaksud dengan aspek perlindungan masyarakat meliputi tujuan mencegah, mengurangi atau mengendalikan tindak pidana dan memulihkan keseimbangan masyarakat (antara lain menyelesaikan konflik, mendatangkan rasa aman, memperbaiki kerugian/kerusakan, menghilangkan noda-noda, memperkuat kembali nilai-nilai yang hidup di dalam masyarakat). Sedangkan yang dimaksud dengan aspek perbaikan si pelaku meliputi berbagai tujuan, antara lain melakukan rehabilitasi dan memasyarakatkan kembali si pelaku dan melindunginya dari perlakuan sewenang-wenang di luar hukum. ${ }^{19}$

Mengenai penyalahguna Napza oleh pelaku anak di bawah umur, pada prinsipnya tidak dapat dituntut pidana. Sanksi hukum pidana hanya ditujukan kepada orang dewasa yang sudah cakap hukum. Hal ini sebagaimana dikemukakan KUHP Pasal 45 menerangkan bahwa: "Dalam hal penuntutan pidana terhadap orang yang belum dewasa karena melakukan suatu perbuatan sebelum umur enam belas tahun, hakim dapat menentukan:memerintahkan supaya yang bersalah dikembalikan kepada orang tuanya, walinya atau pemeliharaannya, tanpa pidana apapun". ${ }^{20}$

Masalah pengaturan mengenai penyalahgunaan Narkotika oleh pelaku anak di bawah umur, secara jelas dapat dilihat pada rumusan Pasal 128 ayat (2) UU No. 35 Tahun 2009 yang mengatakan bahwa: "pecandu Narkotika yang belum cukup umur dan telah dilaporkan oleh orang tua atau walinya sebagaimana dimaksud dalam Pasal 55 ayat (1) tidak dituntut pidana". Pasal tersebut secara jelas menerangkan bahwa bagi anak di bawah umur dalam kasus penyalahgunaan Narkotika tidak dapatdituntut pidana. Namun demikian pihak orang tua dari anak tersebut diharuskan melapor kepada pihak yang berwenang sebagaimana ketentuan Pasal 55 ayat (1) UU No. 35 Tahun 2009: “Orang tua atau wali dari Pecandu Narkotika yang belum

19 Barda Nawawi Arif, Bunga Rampai Kebijakan Hukum Pidana (Bandung: Citra Aditya Bakti, 2002). 224

20 Hamzah, KUHP \& KUHAP. 23 
cukup umur wajib melaporkan kepada pusat kesehatan masyarakat, rumah sakit, dan/atau lembaga rehabilitasi medis dan rehabilitasi sosial yang ditunjuk oleh Pemerintah untuk mendapatkan pengobatan dan/atau perawatan melalui rehabilitasi medis dan rehabilitasi social".

Dalam kaitannya dengan orang tua penyalahguna Narkotika di bawah umur yang sengaja tidak melapor, maka terhadap orang tua tersebut diancam dengan ketentuan pidana sebagaimana diterangkan Pasal 128 ayat (1): "Orang tua atau wali dari pecandu yang belum cukup umur, sebagaimana dimaksud dalam Pasal 55 ayat (1) yang sengaja tidak melapor, dipidana dengan pidana kurungan paling lama 6 (enam) bulan atau pidana denda paling banyak Rp. 1.000.000,00 (satu juta rupiah)".

Ketentuan undang-undang menyebutkan, orang tua atau wali dari pecandu narkotika di bawah usia wajib melaporkan kepada petugas yang ditunjuk pemerintah. Tujuannya agar segera mendapatkan pengobatan dan perawatan yang tepat. Orang tua yang sengaja tidak melapor akan diancam pidana kurungan paling lama 6 bulan atau denda paling banyak Rp 1 juta. Sedangkan pecandu narkotika bila masih di bawah usia dituntut secara pidana.

Pertimbangan pidana dan pelakunya terhadap anak-anak yang melakukan tindak pidana perlu mendapatkan perhatian khusus, sebab pada peradilan anak ini keputusan hakim tersebut harus mengutamakan pemberian bimbingan edukatif terhadap anak-anak disamping tindakan yang bersifat menghukum. Secara yuridis-filosofis, penggunaan hukum pidana sebagai sarana penanggulangan kejahatan yang dilakukan oleh anak pada dasarnya bersifat dilematis. Di satu sisi, penggunaan hukum pidana sebagai sarana penanggulangan kejahatan yang dilakukan anak dengan menempatkan anak sebagai "pelaku" kejahatan akan menimbulkan dampak negatif yang sangat kompleks, tetapi di sisi lain penggunaan hukum pidana sebagai sarana penanggulangan kejahatan anak justru dianggap menjadi "pilihan" yang rasional dan legal.Untuk itu, diperlukan upaya mewujudkan kebijakan penanggulangan kejahatan secara terpadu (integral), maka dalam konteks kebijakan penanggulangan kejahatan anak, hal tersebut perlu dimodifikasi, bukan hanya politik kesejahteraan masyarakat dan politik perlindungan masyarakat secara umum, melainkan diarahkan secara khusus pada politik kesejahteraan anak dan politik perlindungan hak-hak anak, baik anak pada umumnya maupun anak yang menjadi anak pelaku kejahatan (delinquent children) atau korban kejahatan (neglected children) orang dewasa. Sehingga perlu perhatian dan sekaligus pemikiran yang menghasilkan kebijakan yang strategis yang mendasarkan pada pemikiran, bahwa anak-anak adalah tunas harapan bangsa yang akan melanjutkan eksistensi nusa dan bangsa untuk selama-lamanya.

Anak dalam kondisi bagaimanapun harus mendapatkan perlindungan. Kondisi mental anak tidak sama dengan orang dewasa. Pada perinsipnya, perlindungan anak dikategorikan kepada empat hal: Pertama, anak tidak dapat bertanggung jawab sendiri. Salah satu yang digunakan dalam perlindungan anak adalah; anak itu modal utama kelangsungan hidup manusia, bangsa, dan keluarga, untuk itu hak-haknya harus dilindungi. Anak tidak dapat melindungi sendiri hak-haknya,banyak pihak yang mempengaruhi kehidupannya Negara dan masyarakat berkepentingan mengusahakan perlindungan hak-hak anak. Kedua, kepentingan terbaik anak. Agar perlindungan anak dapat diselengarakan dengan baik, dianut prinsip yang menyatakan bahwa kepentingan terbaik anak harus dipandang sebagai of paramount importence (memperoleh perioritas yang tinggi) setiap keputusan yang menyangkut anak. 
Tanpa prinsip ini perjuangan untuk melindungi anak akan mengalami banyak batu sandungan. Prinsip the best interest of the child dugunakan karena dalam banyak hal anak "korban", disebabkan ketidaktahuan karena usia perkembangannya. Jika prinsip ini diabaikan, maka masyarakat akan menciptakan monster-monster yang lebih buruk di kemudian hari. Ketiga, ancangan daur kehidupan. Perlindungan anak mengacu pada pemahaman bahwa perlindungan harus dimulai sejak dini dan terus menerus. Janin yang berada dalam kandungan perlu dilindungi dengan gizi, termasuk yodium dan kalsium yang baik melalui ibunya. Jika ia telah lahir, maka diperlukan air susu ibu dan pelayanan kesehatan primer dengan memberikan pelayanan imunisasi dan lain-lain, sehingga anak terbebas dari berbagai kemungkinan cacat dan penyakit. Masa-masa prasekolah dan sekolah, diperlukan keluarga, lembaga pendidikan, dan lembaga sosial/keagamaan yang bermutu. Anak memperoleh kesempatan belajar yang baik, waktu istrahat dan bermain yang cukup. Keempat, lintas sektoral. Nasib anak tergatung dari berbagai factor makro maupun mikro yang langsung maupun tidak lansung. Kemiskinan, perencaan kota dan segala penggusuran, sistem pendidikan yang menekankan hafalan dan bahan-bahan yang tidak relevan, komunitas yang penuh dengan ketidakadilan, dan sebagainya tidak dapat ditangani oleh sector, terlebih keluarga atau si anak itu sendiri. Perlindungan terhadap anak adalah perjuangan yang membutuhkan sumbangan semua orang di semua tingkatan. ${ }^{21}$

Perbuatan pidana yang ditimbulkan oleh anak di bawah umur, seringkali menimbulkan persoalan yang bersifat dilematis. Hal ini disebabkan tumpulnya hukum pidana bagi anak di bawah umur. Sementara di sisi lain, kejahatan seperti penyalahguna Narkotika merupakan persoalan serius. Berbagai instrumen hukum, baik nasional maupun internasional memberikan isyarat bahwa penanggulangan penyalahgunaan Narkotika yang dilakukan oleh anak melalui penggunaan hukum pidana harus dihindarkan apabila mengorbankan kepentingan anak. Penegakan hukum terhadap anak menjadi tidak bermakna apa-apa apabila ternyata dampak negatif yang ditimbulkannya lebih besar dan lebih berbahaya. Akan tetapi, pengaturan hukum positif yang berlaku di Indonesia secara tegas tidak membenarkan anak dituntut pidana. Sebagaimana dinyatakan dalam Pasal 45 KUHP: "Dalam hal penuntutan pidana terhadap orang yang belum dewasa karena melakukan suatu perbuatan sebelum umur enam belas tahun, hakim dapat menentukan untuk memerintahkan supaya yang bersalah dikembalikan kepada orang tuanya, walinya atau pemeliharaannya, tanpa pidana apapun". Sementara itu, dalam UU No. 35 Tahun 2009 Pasal 128 ayat (2) menerangkan bahwa: "Pecandu Narkotika yang belum cukup umur dan telah dilaporkan oleh orang tua atau walinya sebagaimana dimaksud dalam Pasal 55 ayat (1) tidak dituntut pidana".

Dengan demikian, berdasarkan uraian tersebut dapat disimpulkan bahwa pengaturan tindak pidana pengguna Napza oleh anak di bawah umur diatur oleh UU No. 35 Tahun 2009 Tentang Narkotika. Penyalahgunaan Napza atau Narkotika dan zat adiktif lainnya yang dilakukan oleh anak dibawah umur, berdasarkan ketentuan UU No. 35 Tahun 2009 Pasal 128 Ayat (2), bahwa seorang anak yang melakukan penyalahgunaan Napza tidak dapat dituntut pidana. Meskipun demikian, kepada orang tua anak tersebut diwajibkan untuk melapor. kepada pusat kesehatan masyarakat, rumah sakit, dan/atau lembaga rehabilitasi medis dan rehabilitasi

21 Maidin Gultom, Perlindungan Hukum Terhadap Anak Dalam Sistem Peradilan Anak Di Indonesia (Bandung: Refika Aditama, 2010). 39 
sosial yang ditunjuk oleh Pemerintah untuk mendapatkan pengobatan dan/atau perawatan melalui rehabilitasi medis dan rehabilitasi sosial.

\section{Penyalahgunaan Napza dan Sanksi Hukumnya dalam Persepsi Hukum Islam}

Istilah Napza (Narkotika, Psikotropika, dan Zat Adiktif) dalam hukum Islam, tidak disebutkan secara langsung baik di dalam al-Qur'an maupun di dalam Hadits. Al-Qur'an hanya menyebutkan istilah khamar yaitu sejenis minuman keras yang memabukkan. Khamar sendiri secara etimologi berasal dari bahasa Arab "khamara" yang berarti menutupi. ${ }^{22}$ Maksudnya adalah mengkonsumsi khamr dapat menutupi fungsi kesadaran akal manusia disebabkan sifat memabukkan yang ada di dalamnya. Sementra itu diketahui bahwa Napza merupakan zat atau bahan yang memiliki kandungan psikoaktif yang dapat mengganggu kinerja susunan saraf otak dan dapat mempengaruhi kesadaran. Dalam hukum Islam, kehilangan kesadaran disebut juga mabuk. Sesuatu yang memabukkan, disebut dengan khamar, dan hukumnya adalah haram. Khamr dalam kajian hukum Islam dipandang sebagai sesuatu yang memabukan dan haram mengkonsumsinya. Secara bahasa, katakhamr dalam bahasa arab "menutup" kemudian dijadikan nama bagi segala yang memabukan dan menutup aurat.Kata khamr dipahami sebagai nama minuman yang membuat peminumnya mabuk atau gangguan kesadaran. Pada zaman klasik, cara menkonsumsi benda yang memabukan diolah oleh manusia dalam bentuk minuman sehingga para pelakunya disebut dengan peminum. Pada era modern, benda yang memabukan dikemas menjadi aneka ragam kemasan berupa benda padat, cair, dan gas yang dikemas menjadi bentuk makanan, minuman, tablet, kapsul, atau serbuk, sesuai dengan kepentingan dan kondisi si pemakai. Delik pidana yang dimaksud dalam pembahasan ini, yaitu yaitu seluruh tindakan untuk mengonsumsi makanan atau minuman melalui pencernaan atau jaringa tubuh seperti penyuntikan dan cara yang membuat pemakainya mengalami gangguan kesadaran. ${ }^{23}$

Mengenai keharaman khamar, Allah Swt bersabda di dalam beberapa ayat al-Qur'an surat al-Baqoroh ayat 219 yang artinya: "Mereka bertanya kepadamu (Muhammad) tentang khamar dan judi. Katakanlah bahwa pada keduanya terdapat dosa besar dan ada beberapa manfaat bagi manusia, tetapi dosa keduanya lebih besar daripada manfaatnya". Kemudian di dalam Q.S al-Maidah ayat 90 Allah Swt juga berfirman yang artinya:"Hai orang-orang yang beriman, Sesungguhnya (meminum) khamar, berjudi, (berkorban untuk) berhala, dan mengundi nasib dengan panah adalah perbuatan keji dan termasuk perbuatan syaitan. Maka jauhilah perbuatan-perbuatan itu agar kamu beruntung".

Meminum khamar merupakan perbuatan yang melanggar had Allah, karenanya ia termasuk bagian dari jenis tindak pidana hudud. ${ }^{24}$ Khamar dalam perkembangannya berubah dan bermetamorfosa kepada wujudnya yang semakin berkembang dan tidak terbatas pada benda cair saja. Akan tetapi, di era sekarang ini, terdapat banyak zat yang memabukkan yang bahkan bahayanya lebih buruk daripada benda cair. Seperti misalnya heroin, sabu-sabu, ganja, ekstasi dan lain sebagainya yang dapat mengakibatkan mabuk dan ketergantungan pemakainya. Segala sesuatu yang memabukkan disebut dengan khamr ini didasarkan kepada

${ }^{22}$ Faisal Yahya \& Nida UI Fadhila, "Penyalahgunaan Zat Adiktif Oleh Anak Di Bawah Umur," Jurnal LEGITIMASI 9, no. 1 (2020): 17-45.

23 Zainudin Ali, Hukum Pidana Islam. 78

${ }^{24}$ Ashar, "Konsep Khamar Dan Narkotika Dalam Al-Qur’an Dan UU," Jurnal Fenomena. Vol. 7, No. 2 (2015): $273-96$. 
hadits Nabi Saw yang menyatakan bahwa setiap yang memabukkan adalah khamar, dan setiap khamar adalah haram:

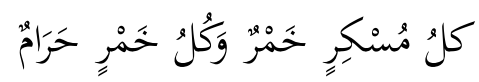

Artinya: "Setiap yang memabukkan itu khamar, dan setiap khamr itu haram" (H.R, Muslim).

Selain daripada hadits tersebut, juga terdapat hadits lain yang menerangkan bahwa sesuatu yang memabukkan dapat disebut khamr, yaitu:

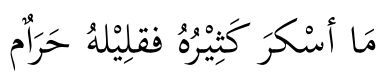

Artinya: "Apa yang banyaknya menyebabkan mabuk, maka sedikitnya pun tetap haram" (H.R, Muslim).

Keharaman khamar karena mempertimbangkan dampaknya yang sangat buruk bagi klesehatan jasmani dan ruhani. Akibat mengkonsumsi khamar atau dalam era modern dapat saja berupa benda padat seperti ekstasi dan lain-lain, memiliki banyak sekali bahaya bahkan dapat mengakibatkan kematian penggunanya.

Selain daripada al-Qur'an, perhatian terhadap larangan mengkonsumsi khamar atau sesuatu yang memabukkan juga banyak datang dari sabda Rasulullah Saw, sebagai berikut:

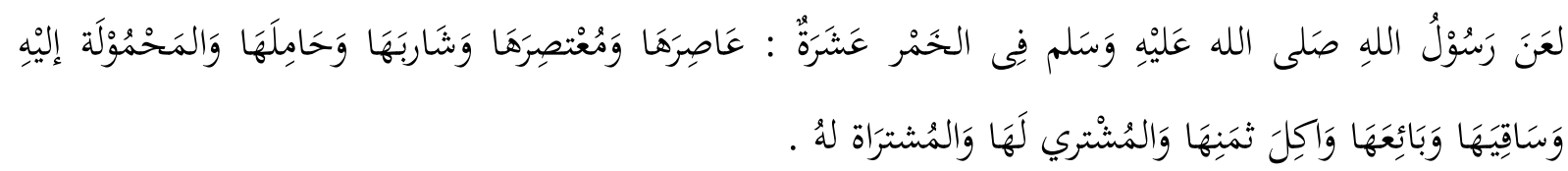

Artinya: "Rasulullah Saw melaknat sepuluh pihak yang berhubungan dengan khamr, yaitu : yang memeras dan meminta diperaskan, yang meminum, yang membawakan dan yang minta dibawakan, yang memberi minum, yang menjual, yang makan hasil penjualannya, yang membeli dan yang dibelikan" (H.R. Turmudzi dan Ibnu Majah).

Islam secara tegas mengharakan khamr atau sesuatu yang memabukkan sejak empat belas abad yang lalu dan hal ini berkaitan dengan penghargaan Islam terhadap akal manusia (hifdz al-'Aql) yang merupakan anugrah Allah Swt yang harus dipelihara sebaik-baiknya. Mengkonsumsi khamar dapat mempengaruhi kesadaran akal. Islam secara jelas menetapkan akal pada posisi yang sangat terhormat serta menjadikannya sebagai salah satu sasaran hukum untuk diamankan, sebagai salah satu Maqashid Syari'ah. Oleh karena itu, ancaman-ancaman yang diarahkan pada akal, mutlak harus dihilangkan.Itulah sebabnya Islam menghukum orangorang yang berupaya menghilangkan ingatannya, dengan hukuman berat. Keberadaan akal (ingatan) pada diri seseorang adalah parameter pembebanan kewajiban bagi seseorang dan ketiadaannya dapat menghilangkan kewajibannya tadi. Apabila seseorang yang sehat akalnya melakukan upaya menghilangkan ingatannya dengan cara meminum-minuman keras berarti sama saja dengan menghindarkan diri dari segala keawjiban. Menghindar dari kewajiban padahal dia sanggup melakukannya adalah perbuatan pidana (jarimah). ${ }^{25}$ Keharaman sesuatu yang memabukkan seperti Napza dalam hukum Islam memiliki kaitan erat dengan prinsip maqhasid as-Syari'ah (tujuan hokum Islam), yakni hifdz al-'aql (pemeliharaan akal). Syahrul Anwar menerangkan bahwa hukum-hukum syari'at Islam itu bertujuan dan harus mampu

25 Hakim, Hukum Pidana Islam.96 
memelihara agama (Hifdu al-Din), memelihara jiwa (Hifdu al-Nafs), Memelihara aqal (Hifdu alAql), memelihara keturunan (Hifdu al-Nasali), dan memelihara harta (Hifdu al-Maal). ${ }^{26}$

Mengenai sanksi hukum, jarimah yang berkenaan dengan Khamr dalam hukum Islam diancam dengan hukuman berupa sanksi jilid mulai dari 40 sampai kepada 80 jilid. ${ }^{27}$ Dalam hal penjatuhan hukuman jilid bagi pelaku pengkonsumsi khamr, terdapat perbedaan mengenai penetapan banyaknya jumlah jilid yang dijatuhkan. Jumhur ulama berpendapat sanksinya adalah 80 kali jilid, namun terdapat juga pendapat lain yang mengatakan bahwa hukuman jilid bagi pelaku jarimah mengkosumsi khamar adalah 40 kali jilid. Pendapat yang mengatakan jumlah sanksi jilid bagi pelaku jarimah ini sebanyak 80 kali, seperti dinyatakan Imam Abu Hanifah dan Imam Malik. Sementara pendapat yang mengatakan 40 kali jilid adalah pendapat Imam Syafi'i meskipun beliau membolehkan penguasa untuk menambah hukumannya sampai delapan puluh kali jilid. Jumlah jilid selebihnya dari 40 kali, menurut Imam syafi'I tidak termasuk kepada hukuman had, melainkan ta'zir. Adanya ikhtilaf atau perbedaan pendapat mengenai penetapan jumlah sanksi jilid bagi pelaku pengkonsumsi khamar, didasarkan kepada hadits Nabi Saw:

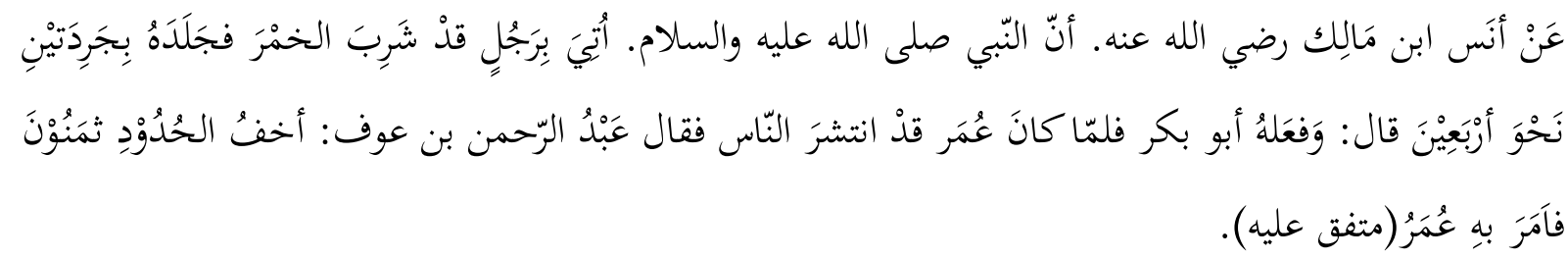

Artinya: "Dari Anas bin Malik r.a bahwa Nabi Saw pernah didatangi seorang laki-laki yang telah meminum khamjar, maka nabi menderanya dengan dua pelepah kurma sebanyak empat pul; uh kali, hal ini dilakukan oleh Abu Bakar. Akan tetapi, kata Abdurrahman bin Auf, paling rendah hukuman itu adalah delapan pulu kali, maka umar memerintahkan begitu" (Mutafaq 'alaih).

Rahmat Hakimmenerangkan bahwa terdapatnya matan hadits tersebut mengakibatkan terjadinya perbedaan pendapat di kalangan ulama fuqoha. Sebagian mengatakan hukuman jilid peminum khamar adalah 80 kali, seperti dikatakan Imam Malik dan Abu Hanifah. Sebagian lagi mengatakan 40 kali, seperti yang dipahami Imam Syafi'i, walaupun pendapat terakhir ini membolehkan kalau dikehendaki penguasa/Ulil Amri, penambahan empat puluh kali lagi sebagai hukuman ta'zir. ${ }^{28}$ Pendapat yang mengatakan hukuman jilid bagi peminum khamar sebanyak 80 jilid dasarnya adalah ijma' para sahabat seperti dalam riwayat yang menceritakan bahwa umar telah mengadakan musyawarah dengan masyarakat mengenai hukuman peminum khamar. Pada waktu itu Abdurrahman bin Auf mengatakan bahwa hukuman dimaksud harus disamakan dengan hukuman teringan dalam bab hukuman, yakni delapan puluh kali pukulan. Pendapat ini disepakati umar dan kemudian diberitahukan kepada Khalid bin Walid dan Abu Ubaidah, gubernur Syam.

Berdasarkan uraian tersebut dapat dipahami bahwa mengkonsumsi khamar adalah haram dan diancam oleh hukum pidana Islam dengan sanksi jilid. Dalam penetapan hukuman

${ }^{26}$ Syahrul Anwar, IImu Fiqih Dan Ushul Fiqih (Bandung: Fakultas Syari'ah dan Hukum UIN Sunan Gunung Djati, 2009).

27 Hakim, Hukum Pidana Islam. 95

28 Hakim. Hukum Pidana Islam. 101 
jilid pada jarimah ini, terdapat perbedaan pendapat di kalangan ulama, sebagian mengatakan 80 kali jilid seperti yang dipahami oleh Imam Malik dan Abu Hanifah. Sedangkan Imam Syafi'i berpendapat 40 kali meskipun diperbolehkan untuk menambahnya sampai 40 kali lagi sebagai hukuman ta'zir. Meskipun terdapat perbedaan, pada prinsipnya mengkonsumsi khamr adalah sesuatu yang dilarang dan harus ditinggalkan disebabkan khamr lebih banyak madharatnya daripada manfaatnya.Namun demikian penyalahgunaan Napza yang dilakukan oleh pelaku anak dibawah umur mengundang perhatian yang cukup serius. Dalam hukum Islam, seorang anak di bawah umur tidak dapat kenai pembebanan hukum, tidak terkena khitab (panggilan) karena tidak termasuk mukallaf. Orang yang tidak mukallaf (aqil baligh), bebas dari aturan hukum syara dan tidak dapat dikenai pertanggung jawaban pidana (al-masuliyyah al-jiniyah. Tidak dapatnya dimintai pertanggung jawaban pidana dalam perbuatan jarimah yang dilakukan oleh anak di bawah umur, didasarkan pada sebuah kaidah yang menyatakan bahwa:

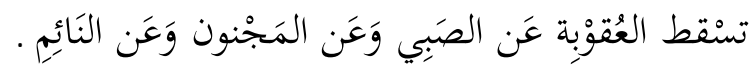

Artinya: "Hukuman gugur dari (perbuatan jarimah yang dilakukan oleh) anak-anak, orang gila, dan orang yang sedang tidur" ${ }^{29}$

Kaidah tersebut menjelaskan bahwa hukuman menjadi gugur, maksudnya tidak dapat dijatuhkan kepada pelaku jarimah apabila perbuatan jarimah tersebut dilakukan oleh anak kecil, orang gila dan orang yang sedang dalam keadaan tidur. Mereka tidak termasuk kepada orang yang mendapat khitab (panggilan) untuk melaksanakn hukum disebabkan mereka bukan pada keadaan taklif atau aqil-baligh. Rahmat Hakim menerangkan bahwa seorang pembuat jarimah haruslah orang yang dapat memahami hukum, mengerti isi bebab, dan sanggup menerima beban tersebut. Orang yang diasumsikan memiliki kriteria tersebut adalah orangorang yang mukallaf, sebab hanya merekalah yang terkena khitab (panggilan) pembebanan atau taklif. ${ }^{30}$ Oleh sebab itu pembuat tindak pidana atau delik haruslah orang yang dapat mempertanggungjawabkan perbuatannya agar dapat dimintai pertanggung jawaban pidana (al-mas'uliyah al-jinaiyyah). Sementara itu, Zainudin Ali juga berpendapat bahwa pada prinsipnya yang dimaksud dengan jarimah (tindak pidana), adalah perbuatan kriminal yang dilakukkan oleh orang-orang mukallaf (orang yang dapat dibebani kewajiban). ${ }^{31}$ Dengan demikian dapat dipahami bahwa tidak dikatakan suatu tindak pidana apabila pelakunya bukan orang Mukallaf. Orang yang dapat dimintai pertanggung jawaban pidana hanya orang dewasa yang mukallaf (aqil baligh). Oleh karena itu, unsur moril (rukun adaby) dalam sebuah perumusan tindak pidana (jarimah) menjadi sangat penting karena akan menentukan dapat dan tidaknya suatu perbuatan dikatakan sebagai sebuah tindak pidana.

Berdasarkan uraian tersebut, dapat disimpulkan bahwa dalam sudut pandang hukum pidana Islam, perbuatan penyalahgunaan Napza yang dilakukan oleh anak di bawah umur tidak bisa dikenai sanksi hukum. Hal ini didasarkan pada alasan bahwa anak di bawah umur tidak dapat dimintai pertanggungjawaban pidana disebabkan mereka belum mencapai aqil baligh (mukallaf) untuk dapat dikenai beban panggilan hukum (khitab). Selain dari pada itu, dalam suatu perumusan tindak pidana disyaratkan pelaku haruslah orang yang dapat

\footnotetext{
${ }^{29}$ Faizal, Kaidah Fiqh Jinayah (Asas-Asas Hukum Pidana Islam). 76

30 Hakim, Hukum Pidana Islam. 53

${ }^{31}$ Ali, Hukum Pidana Islam. 1
} 
mempertanggungjawabkan perbuatannya secara hukum. Keharusan ini dalam hukum Islam disebut dengan unsur moril (rukn adaby), yang mengharuskan pelaku jarimah adalah orang dewasa atau mukallaf sehingga dapat dimintai pertanggung jawaban atas perbuatannya. Namun demikian penyalahgunaan Napza oleh anak di bawah umur harus tetap menjadi perhatian semua pihak, mulai dari pemertintah, orang tua dan masyarakat secara luas mengingat dampaknya yang bisa mengancam keutuhan hidup bermasyarakat, mengingat dampak yang ditimbulkan tidak hanya dari segi fisik dan psikis penyalahguna, melainkan juga dampak sosial yang berhubungan dengan tatanan sosial di masyarakat. Selain itu, di dalam hukum Islam pemeliharaan terhadap generasi penerus dalam hal ini adalah anak-anak dan juga pemeliharaan terhadap akal (kesadaran) manusia menjadi prioritas yang harus diutamakan di dalam hukum Islam, yakni memelihara keturunan ( $h i f d z$ al-Nasl) dan memelihara akal (hifdz al'Aql) yang termasuk ke dalam salah satu dari 5 (lima) hal utama yang menjadi tujuan hukum Islam atau dalam istilah ilmu hukum Islam disebut dengan maqoshid as-Syari'ah.

\section{SIMPULAN}

Pengaturan penyalahgunaan Napza yang di lakukan oleh anak dibawah umur, diatur oleh Undang-Undang No. 35 Tahun 2009 tentang Narkotika. Berdasarkan ketentuan UndangUndang Nomor 35 Tahun 2009 Pasal 128 Ayat (2), dinyatakan bahwa seorang anak yang melakukan penyalahgunaan Narkotika dan zat adiktif lainnya, tidak dapat dituntut pidana. Sementara itu, dalam KUHP Pasal 45 juga diterangkan bahwa seorang anak tidak dapat dituntut pidana sebelum ia mencapai dewasa. Dengan demikian bahwa penyalahgunaan Napza oleh pelaku anak di bawah umur tidak dapat dimintai pertanggung jawaban pidana dikarenakan seorang anak di bawah umur dikatakan tidak cakap hukum. Meskipun tidak dapat dituntut pidana, kepada orang tua anak tersebut diwajibkan untuk melapor kepada pusat kesehatan masyarakat, rumah sakit, dan/atau lembaga rehabilitasi medis dan rehabilitasi sosial yang ditunjuk oleh Pemerintah untuk mendapatkan pengobatan dan/atau perawatan melalui rehabilitasi medis dan rehabilitasi sosial. Dalam persepsi hukum Islam, Napza dipandang sebagai zat yang dapat mempengaruhi kesadaran akal dan mengakibatkan mabuk dan dikategorikan kepada khamr, dengan alasan bahwa pada keduanya sama-sama dapat memabukkan. Mengkonsumsi khamr, dalam hukum pidana Islam termasuk kepada jarimah hudud, apabila unsur jarimahnya terpenuhi. Salah satu unsur tindak pidana (jarimah), adalah pelakunya harus orang dewasa atau aqil-baligh (mukallaf). Apabila pelakunya bukan mukallaf, maka jarimah menjadi gugur, artinya si pembuat jarimah tidak dapat dijatuhi sanksi hukum. Dengan demikian, berdasarkan sudut pandang hukum pidana Islam, penyalahgunaan Napza yang dilakukan oleh anak di bawah umur tidak dapat dikenai sanksi hukum. Hal ini didasarkan pada alasan bahwa anak di bawah umur tidak dapat dimintai pertanggungjawaban pidana (almasuliyah al-jinaiyah) disebabkan mereka belum mencapai aqil baligh (mukallaf).

\section{DAFTAR PUSTAKA}

\section{Buku}

Ali, Zainuddin. 2007. Hukum Pidana Islam. Jakarta: Sinar Grafika.

Anwar, Syahrul. 2009. IImu Fiqih Dan Ushul Fiqih. Bandung: Fakultas Syari'ah dan Hukum UIN Sunan Gunung Djati. 
Arif, Barda Nawawi. 2002. Bunga Rampai Kebijakan Hukum Pidana. Bandung: Citra Aditya Bakti. BNN. 2009. Pusat Pencegahan Badan Narkotika Nasional Republik Indonesia Tahun 2009. Jawa Barat: Bidang Pencegahan Badan Narkotika Provinsi Jawa Barat.

Edikarsono. 2004. Mengenal Kecanduan Narkoba Dan Minuman Keras. Bandung: Yrama Widya. Gultom, Maidin. 2010. Perlindungan Hukum Terhadap Anak Dalam Sistem Peradilan Anak Di Indonesia. Bandung: Refika Aditama.

Hakim, Rahmat. 2020. Hukum Pidana Islam. Bandung: Pustaka Setia.

Hamzah, Andi. 2008. KUHP \& KUHAP. Jakarta: Rineka Cipta.

Joewana, Lidya Harlina Martono dan Satya. 2006. Membantu Pemulihan Pecandu Narkoba Dan Keluarganya. Jakarta: Balai Pustaka.

Mubarok,Jaih dan Faizal,Enceng Arif. 2004. Kaidah Figh Jinayah (Asas-Asas Hukum Pidana Islam). Bandung: Pustaka Bani Quraisy.

Artikel Jurnal

Ashar.(2015). “Konsep Khamar Dan Narkotika Dalam Al-Qur’an Dan UU." Jurnal Fenomena. Vol. 7, (2), 273-96.

Azmiyati, Siti Riza, dkk. (2014). "Gambaran Penggunaan Napza Pada Anak Jalanan Di Kota Semarang." Jurnal Kesehatan Masyarakat. Vol. 9 (2), 137-43.

Eleanora, Fransiska Novita. (2011)."Bahaya Penyalahgunaan Narkoba Serta Usaha Pencegahan Dan Penanggulangannya." Jurnal Hukum. Vol. XXV,(1), 439-52.

Faizal, Liky. (2015). "Penyalahgunaan Narkoba Dalam Pandangan Islam (Upaya Pencegahan Dan Solusi Penyalahgunaan Narkoba)." Jurnal ASAS. Vol. 7 (35), 131-36.

Hidayati, Ilmi. (2016). "Metode Dakwah Dalam Menguatkan Resilensi Korban Penyalahgunaan Narkotika, Psikotropika, Dan Zat Adiktif Lainnya (NAPZA)." Jurnal IImu Dakwah. Vol. 36(1), 170-87.

Nurmaya, Alya. (2016). "Penyalahgunaan Napza Di Kalangan Remaja ( Studi Kasus Pada 2 Siswa Di MAN 2 Kota Bima )." Jurnal Psikologi Pendidikan \& Konseling. Vol. 2 (1) 26-32.

Siregar, Amru Eryandi, dkk. (2017) . "Penjatuhan Sanksi Pidana DiBawah Batas Minimum Ancaman Hukuman Bagi Anak Pelaku Tindak Pidana Narkotika." USU Law Journal. Vol. 5, (2), 182-91.

Sutono, Dimas Adit, dkk. (2020). "Penerapan Sanksi Pidana Kepada Anak Dibawah Umur Pemakai Narkotika (Studi Pada Polrestabes Medan)." Journal Sociaty Law (JSL). Vol. 1, (1), 14-24.

Suyatna, Uyat. (2018). "Evaluasi Kebijakan Narkotika Pada 34 Provinsi Di Indonesia." Jurnal IImu-IImu Sosial Dan Humaniora. Vol. 20 (2), 168-76.

Yahya, Faisaldan Fadhila, Nida UI. (2020). "Penyalahgunaan Zat Adiktif Oleh Anak Di Bawah Umur." Jurnal Legitimasi. Vol. 9 (1), 17-45.

Wulandari, Catur Mei. (2015). "Faktor-faktor yang Mempengaruhi Penyalahgunaan Napza pada Masyarakat di Kabupaten Jember." Jurnal Farmasi Komunitas. Vol. 2 (1), 1-4.

\section{Peraturan Perundang-undangan}

Undang-undang Nomor 35 Tahun 2009 tentang Narkotika, (Lembaran Negara Repblik Indonesia Tahun 2009 Nomor 5062).

Undang-undang Nomor 5 Tahun 1997 Tentang Psikotropika, (Lembaran Negara Repblik Indonesia Tahun 1997 Nomor10).

Undang-Undang Nomor 23 Tahun 2002 Tentang Perlindungan Anak, (Lembaran Negara Repblik Indonesia Tahun 2002 Nomor109). 